\title{
PENGARUH STRATEGI PEMBELAJARAN REACT TERHADAP KEMAMPUAN KOMUNIKASI MATEMATIS SISWA SMP BERDASARKAN GENDER
}

\author{
Tonnie Hari Nugraha ${ }^{1}$, Hepsi Nindiasari ${ }^{2}$, Syamsuri $^{3}$ \\ 1,2,3 Universitas Sultan Ageng Tirtayasa \\ ${ }^{1}$ tonniehn@gmail.com \\ ${ }^{2}$ hepsinindiasari@untirta.ac.id \\ ${ }^{3}$ syamsuri@untirta.ac.id
}

\begin{abstract}
ABSTRAK
Penelitian ini bertujuan untuk menguji dan mengkaji peningkatan kemampuan komunikasi matematis siswa baik secara keseluruhan maupun berdasarkan gender. Subjek dalam penelitian ini adalah siswa kelas 8 SMPN 1 Cikulur. Teknik pengumpulan data menggunakan pretes dan postes kemampuan komunikasi matematis. Dari data pretes dan postes diperoleh data n-gain kemudian dianalisis dengan menggunakan ANOVA dua-jalur untuk melihat peningkatan kemampuan komunikasi matematis siswa. Hasil penelitian diperoleh bahwa peningkatan kemampuan komunikasi matematis siswa yang memperoleh pembelajaran melalui strategi Relating, Experiencing, Applying, Collaborating, Transferring (REACT) lebih tinggi daripada siswa yang memperoleh pembelajaran ekspositori ditinjau dari keseluruhan siswa, peningkatan kemampuan komunikasi matematis siswa laki-laki yang memperoleh pembelajaran melalui strategi REACT lebih tinggi daripada siswa laki-laki yang memperoleh pembelajaran ekspositori, peningkatan kemampuan komunikasi matematis siswa perempuan yang memperoleh pembelajaran melalui strategi REACT lebih tinggi daripada siswa perempuan yang memperoleh pembelajaran ekspositori, tetapi tidak terdapat perbedaan peningkatan kemampuan komunikasi matematis antara siswa perempuan dan siswa laki-laki yang memperoleh pembelajaran melalui strategi REACT.
\end{abstract}

Kata Kunci : kemampuan komunikasi matematis, REACT, gender.

\begin{abstract}
This study aims to examine an improvement of students' mathematical communication skills. The subjects in this study were 8th grade students of Cikulur 1 Junior High School. Data collection techniques using test techniques in the form of pretest and posttest mathematical communication skills. From the pretest and posttest data obtained n-gain data were then analyzed using 2-way ANOVA to see the improvement of students' mathematical communication skills. The results showed that the increase in mathematical communication skills of students who obtained learning through Relating, Experiencing, Applying, Collaborating, Transferring (REACT) strategies was higher than that of students who obtained expository learning, the increase in mathematical communication skills of male students who obtained learning through REACT strategies was higher than male students who obtained expository learning, an increase in mathematical communication skills of female students who obtain learning through REACT strategies is higher than female students who have expository learning, but there is no difference between female students and male students who receive learning through the REACT strategy in mathematical communication skills.
\end{abstract}

Keywords: mathematical communication skills, REACT, gender 


\section{PENDAHULUAN}

Matematika adalah salah satu mata pelajaran yang terdapat dalam struktur kurikulum dan diajarkan pada setiap jenjang satuan pendidikan. Salah satu kompetensi matematika menurut Permendikbud Nomor 21 tahun 2016 tentang Standar Isi adalah memiliki kemampuan mengkomunikasikan gagasan matematika dengan jelas dan menunjukkan sikap logis, kritis, analitis, cermat dan teliti, bertanggung jawab, responsif, dan tidak mudah menyerah dalam memecahkan masalah. Sejalan dengan itu, kemampuan matematis siswa yang dirumuskan oleh National Council of Teachers of Mathematics (2000) dalam tujuan umum pembelajaran matematika yaitu; kemampuan pemecahan masalah (problem solving), kemampuan komunikasi (communication), kemampuan koneksi (connection), kemampuan penalaran (reasoning), dan kemampuan representasi (representation). Berdasarkan tujuan pembelajaran matematika di atas, disimpulkan bahwa kemampuan komunikasi matematis merupakan kemampuan yang sangat penting untuk dikuasai oleh siswa.

Menurut Prayitno, Suwarsono, dan Siswono (2013) komunikasi matematika adalah suatu cara siswa untuk menyatakan dan menafsirkan gagasan-gagasan matematika secara lisan maupun tertulis, baik dalam bentuk gambar, tabel, diagram, rumus, ataupun demonstrasi. Menurut NCTM (2000) disebutkan bahwa standar kemampuan komunikasi matematis adalah: 1) kemampuan siswa dalam menjelaskan dan mengungkapkan pemikiran mereka tentang ide matematika secara tertulis ataupun lisan, 2) kemampuan siswa untuk merepresentasikan gambar, grafik, atau diagram ke dalam ide matematika, 3) menggunakan bahasa/notasi matematika secara tepat dalam berbagai ide matematika.

Menurut Sumarmo (2003) dijelaskan bahwa kemampuan komunikasi matematis merupakan kemampuan yang mencakup: 1) merefleksikan benda-benda nyata, gambar, atau ide-ide matematika; 2) menjelaskan idea, situasi dan relasi matematik secara lisan atau tulisan dengan benda nyata, gambar, grafik, dan aljabar; 3) mendengarkan, berdiskusi dan menulis tentang matematika; 4) menyatakan peristiwa sehari-hari dalam bahasa atau simbol matematika; 5) membaca dengan pemahaman suatu presentasi matematika tertulis; 6) membuat konjektur, menyusun argument, merumuskan definisi, dan generalisasi; dan 7) menjelaskan dan membuat pertanyaan tentang matematika yang telah dipelajari. Sedangkan Ansari (2012) menyebutkan indikator untuk mengukur kemampuan komunikasi matematis siswa terbagi dalam tiga kelompok, yaitu: 1) menggambar/drawing, yaitu merefleksikan benda-benda nyata, gambar dan diagram ke dalam ide-ide matematika. Atau sebaliknya, dari ide-ide matematika ke dalam bentuk gambar atau diagram, 2) ekspresi 
matematika/mathematical expression, yaitu mengekspresikan konsep matematika dengan menyatakan peristiwa sehari-hari dalam bahasa atau simbol matematika, 3) menulis/written texts, yaitu memberikan jawaban dengan menggunakan bahasa sendiri, membuat model situasi atau persoalan menggunakan bahasa lisan, tulisan, grafik, dan aljabar, menjelaskan, dan membuat pertanyaan tentang matematika yang telah dipelajari, mendengarkan, mendiskusikan, dan menulis tentang matematika, membuat konjektur, menyusun argumen, dan generalisasi.

Kemampuan komunikasi matematis merupakan kemampuan penting yang harus dikembangkan dan dimiliki oleh siswa. Akan tetapi, hasil laporan dari Puspendik Balitbang Depdiknas (Wardhani \& Rumiati, 2011) menyatakan bahwa siswa Indonesia lemah dalam mengerjakan soal-soal yang menuntut kemampuan pemecahan masalah, berargumentasi dan berkomunikasi. Kurangnya kemampuan komunikasi matematis siswa dikarenakan siswa kurang dibiasakan untuk menyelesaikan soal dengan cara memberi argumentasi.

Survei yang dilakukan oleh Programme for International Student Assesment (PISA) dengan mengukur literasi matematis siswa sekolah berusia 15 tahun menunjukkan bahwa pada tahun 2012 Indonesia menduduki peringkat ke-64 dari 65 negara dengan rerata skor 375. Hasil ini sangat jauh dari rerata skor internasional dengan jumlah 500. Pada tahun 2015 peringkat Indonesia mengalami penurunan yaitu peringkat ke-63 dari 70 negara dengan rerata skor 386 (Organisational for Economic Co-Operation and Development [OECD], 2016). Literasi matematis diartikan sebagai kemampuan siswa dalam analisis, penalaran, dan komunikasi secara efektif pada saat menampilkan, memecahkan dan menginterpretasikan masalah-masalah matematis. Dengan demikian, fakta yang diperoleh dari laporan PISA tampak bahwa kemampuan komunikasi matematis siswa Indonesia masih rendah.

Hasil observasi terhadap 60 siswa kelas IX di SMPN 1 Cikulur pada bulan November tahun 2018, dengan memberikan soal tes kemampuan komunikasi matematis. Soal yang diberikan sebanyak tiga buah dalam bentuk uraian dengan indikator, yaitu kemampuan menyatakan suatu situasi ke dalam bentuk gambar, kemampuan menyatakan suatu situasi ke dalam model matematika dan kemampuan menjelaskan suatu gambar ke dalam bentuk ide matematis. Hasil yang diperoleh dari observasi tersebut yakni rata-rata nilai kemampuan matematis siswa adalah 33,2 dari skor maksimum 100 (Nugraha \& Pujiastuti, 2019). Ini menunjukkan kemampuan komunikasi matematis siswa SMP Negeri 1 Cikulur masih rendah. Dari beberapa temuan di atas, diperoleh gambaran bahwa kemampuan komunikasi matematis siswa dinilai masih belum optimal sehingga diperlukan 
suatu pembelajaran yang mampu mengembangkan sehingga dapat meningkatkan kemampuan komunikasi matematis siswa.

Pemilihan strategi mengajar yang tepat dan pengaturan lingkungan belajar memiliki pengaruh yang signifikan terhadap kesuksesan pelajaran matematika (Bell, 1978). Salah satu pendekatan pembelajaran yang cocok untuk diterapkan dalam upaya meningkatkan kemampuan pemecahan masalah dan komunikasi matematis siswa di antaranya pendekatan kontekstual. Pendekatan ini merupakan suatu pendekatan pembelajaran yang bertitik tolak dari hal -hal yang nyata atau yang sering dialami siswa. Pemikiran siswa tidak langsung tertuju pada konsep matematika yang abstrak, tetapi diantarkan terlebih dahulu melalui permasalahan nyata yang selanjutnya diubah ke dalam konsep abstrak.

Melalui pembelajaran kontekstual, guru bukan satu-satunya sebagai sumber informasi, tetapi guru lebih banyak menjadi fasilitator untuk membantu siswa agar dapat memahami keterkaitan antar konsep yang dipelajari dengan konteks kehidupan sehari-hari. Hal ini sesuai dengan pengertian Contextual Teaching and Learning (CTL) yang dikemukakan oleh Jhonson (Suhena, 2009) bahwa CTL merupakan suatu pendekatan pembelajaran yang bertujuan membantu siswa melihat makna dalam bahan pembelajaran yang mereka pelajari dengan cara menghubungkannya dengan konteks kehidupan seharihari. Banyak ahli menggambarkan bahwa siswa belajar ketika mereka memperoleh pengetahuan melalui eksplorasi dan pembelajaran aktif. Strategi ini mendorong siswa untuk berpikir dan menjelaskan penalaran mereka daripada sekedar mengingat fakta, membantu siswa untuk melihat hubungan antara berbagai tema dan konsep (Crawford, 2001).

Salah satu strategi dalam pembelajaran kontekstual adalah yang memunculkan lima strategi yaitu Relating, Experiencing, Applying, Cooperating dan Transferring dikenal dengan strategi REACT. Relating berarti menghubungkan dengan pengetahuanpengetahuan yang telah dimiliki siswa, Experiencing berarti memberikan pengalaman belajar siswa melalui kegiatan membangun dan menemukan pengetahuannya sendiri, Applying berarti menerapkan pengetahuan yang telah dimiliki untuk memecahkan masalah yang dihadapi, Cooperating berarti saling berbagi, saling merespon dan berkomunikasi dengan sesame teman, dan Transferring berarti menggunakan pengetahuannya pada konteks permasalahan baru (Crawford, 2001). Kelima strategi ini sejalan juga dengan pendekatan saintifik yang diamanatkan oleh Kurikulum 2013 yang menekankan pada active learning. 
Terdapat beberapa penelitian yang relevan yang sudah dilakukan diantaranya adalah penelitian yang dilakukan oleh Tapilouw (2010) yang menyebutkan bahwa kemampuan matematis siswa (pemahaman, penalaran, dan komunikasi) yang mengalami pembelajaran melalui pendekatan REACT lebih tinggi daripada siswa yang belajarnya konvensional, serta kemampuan matematis siswa sekolah peringkat tinggi, sedang dan rendah yang mengalami pembelajaran melalui REACT juga lebih tinggi daripada siswa yang belajarnya secara konvensional. Begitupun hasil penelitian yang diakukan oleh Kaselin, Sukestiyarno, \& Waluta (2013) yang menyatakan bahwa kemampuan komunikasi matematis siswa yang menggunakan pembelajaran dengan strategi REACT berbasis etnomatematika lebih baik dari siswa yang menggunakan pembelajaran model ekspositori. Penelitian ini diperkuat oleh hasil penelitian yang dilakukan oleh Husna, Dewi, \& Murni, (2014) juga menyebutkan bahwa kemampuan pemahaman konsep matematika siswa yang mengikuti pembelajaran dengan strategi REACT lebih tinggi daripada kemampuan pemahaman konsep matematika siswa yang mengikuti pembelajaran konvensional.

Banyak faktor yang perlu diperhatikan dalam mempelajari matematika, diantaranya perbedaan jenis kelamin siswa (gender). Perbedaan gender bukan hanya berakibat pada perbedaan kemampuan dalam matematika, tetapi cara memperoleh pengetahuan matematika. Keitel (1998) menyatakan "Gender, social, and cultural dimensions are very powerfully interacting in conceptualization of mathematics education,...". Berdasarkan pendapat Keitel bahwa gender, sosial dan budaya berpengaruh pada pembelajaran matematika.

Jenis kelamin yang berbeda ternyata juga memunculkan karakter dan struktur otak yang berbeda, sehingga menghasilkan cara dan gaya belajar yang berbeda pula. Laki-laki lebih mudah mempelajari sesuatu dengan cara yang mengedepankan aktifitas hands-on seperti praktikum, desain, merangkai alat, dan sebagainya, dan minim komunikasi (verbal dan non-verbal). Sedangkan perempuan, lebih senang belajar dengan cara dan gaya yang berkaitan dengan komunikasi seperti ceramah, berbicara, menulis, diskusi santai, dan presentasi. Potensi tersebut harus bisa dioptimalkan dengan proses pendidikan yang sesuai (Amin, 2018).

Perbedaan gender masih berpengaruh di sekolah menengah pada pembelajaran matematika dalam penyelesaian masalah yang kompleks (Lindberg, Hyde, Petersen, \& Linn, 2010). Berbagai faktor dapat menjelaskan tentang kesenjangan gender ini, diantaranya pola minat yang dibentuk oleh budaya, status sosial ekonomi, pendidikan 
orangtua dan kualitas sekolah. Oleh karena itu aspek gender perlu menjadi perhatian khusus dalam pembelajaran matematika.

Penelitian tentang kemampuan matematis ditinjau dari gender masih menunjukan hasil yang beragam. Begitupun penelitian terkait peningkatan kemampuan komunikasi matematis siswa melalui berbagai pembelajaran menunjukkan hasil yang signifikan. Sementara penelitian terkait pembelajaran melalui strategi REACT pun telah dilakukan. Namun penelitian yang mengkaji kemampuan komunikasi matematis siswa SMP melalui strategi REACT berdasarkan gender belum pernah dilakukan. Oleh karena itu akan dilakukan penelitian mengenai peningkatan kemampuan komunikasi dan pemecahan masalah matematis siswa SMP melalui strategi REACT berdasarkan gender.

Berdasarkan pada latar belakang yang telah diuraikan sebelumnya, maka rumusan masalah dalam penelitian ini adalah: 1) apakah peningkatan kemampuan komunikasi matematis siswa yang memperoleh pembelajaran melalui strategi REACT lebih tinggi daripada siswa yang memperoleh pembelajaran ekspositori ditinjau dari keseluruhan siswa?, 2) apakah peningkatan kemampuan komunikasi matematis siswa laki-laki yang memperoleh pembelajaran melalui strategi REACT lebih tinggi daripada siswa laki-laki yang memperoleh pembelajaran ekspositori, 3) apakah peningkatan kemampuan komunikasi matematis siswa perempuan yang memperoleh pembelajaran melalui strategi REACT lebih tinggi daripada siswa perempuan yang memperoleh pembelajaran ekspositori, 4) apakah terdapat perbedaan peningkatan kemampuan komunikasi matematis antara siswa perempuan dan siswa laki-laki yang memperoleh pembelajaran melalui strategi REACT?

\section{METODE PENELITIAN}

Penelitian ini dilakukan di SMP Negeri 1 Cikulur Kabupaten Lebak Propinsi Banten. Metode yang digunakan dalam penelitian ini adalah metode kuasi-eksperimen. Dua kelas yang digunakan dalam penelitian merupakan kelas yang sudah ada, karena peneliti tidak membentuk kelas baru yang akan mengganggu kegiatan pembelajaran di kelas asal siswa. Namun penentuan kelas yang menjadi kelas eksperimen maupun kontrol ditentukan secara acak dengan kemampuan disetiap kelas bersifat homogen (bukan kelas unggulan). Dalam penelitian ini diambil dua kelas sebagai sampel, yaitu kelas eksperimen yang memperoleh pembelajaran melalui stategi REACT dan kelas kontrol yang memperoleh pembelajaran ekspositori. Dalam setiap kelas, baik kelas eksperimen dan 
kelas kontrol terdiri atas siswa laki-laki dan siswa perempuan dengan jumlah yang hampir sama antara siswa laki-laki dan siswa perempuan.

Sebelum pembelajaran dilaksanakan, pada kelas eksperimen maupun kelas kontrol diberikan pretes kemampuan komunikasi matematis untuk mengetahui sejauh mana kemampuan awal komunikasi matematis siswa. Di akhir pembelajaran pada kelas eksperimen maupun kelas kontrol diberikan postes kemampuan komunikasi matematis untuk mengetahui sejauh mana kemampuan komunikasi matematis siswa setelah diberikan perlakuan.

Populasi penelitian ini adalah siswa SMP Negeri 1 Cikulur kelas VIII tahun pelajaran 2018/2019. Subjek dalam penelitian ini adalah siswa kelas VIII karena terdapat materi yang membutuhkan kemampuan komunikasi masalah matematis khususnya materi Bangun Ruang Sisi Datar.

Teknik pengambilan sampel pada penelitian ini adalah cluster random sampling, yaitu teknik pengambilan sampel berdasarkan daerah populasi yang telah ditetapkan (Sugiyono, 2013). Satu kelas dijadikan kelas eksperimen dan kelas lainnya dijadikan kelas kontrol. Pada kelas eksperimen dilaksanakan pembelajaran melalui strategi REACT sedangkan pada kelas kontrol dilaksanakan pembelajaran dengan ekspositori.

Penelitian ini akan dilakukan dalam empat tahapan kegiatan, yaitu: tahap persiapan, tahap pelaksanaan, tahap analisis data, dan tahap pembuatan kesimpulan. Pada tahap persiapan, peneliti melakukan beberapa kegiatan yang dilaksanakan untuk mempersiapkan pelaksanaan kegiatan, diantaranya menyusun instrumen tes untuk mengukur kemampuan komunikasi dan pemecahan masalah matematis.

Adapun indikator kemampuan komunikasi matematis dalam penelitian ini adalah: 1) menyatakan suatu situasi ide matematis ke dalam bentuk gambar dan menyelesaikannya (drawing), 2) menyatakan suatu situasi atau ide matematis ke dalam bentuk simbol atau model matematis dan menyelesaikannya (mathematical expression), 3) menyatakan dan menjelaskan suatu gambar atau model matematis ke dalam bentuk ide matematis (written texts).

\section{HASIL DAN PEMBAHASAN}

Berdasarkan hasil penelitian, diperoleh data kuantitatif berupa skor pretes dan postes kemampuan komunikasi matematis (MCS) siswa yang memperoleh pembelajaran dengan strategi REACT (SR) dan pembelajaran ekspositori (PE). Selanjutnya skor tersebut digunakan untuk menghitung gain ternormalisasi (n-gain) MCS baik pada 
kelas SR maupun kelas PE. Uji perbedaan dua rerata terhadap data n-gain MCS dilakukan untuk menjawab rumusan masalah mengenai perbedaan peningkatan MCS antara siswa kelas SR dan siswa kelas PE, baik ditinjau dari keseluruhan siswa maupun berdasarkan gender. Sebelum data dianalisis, terlebih dahulu dilakukan uji prasyarat yaitu uji normalitas dan uji homogenitas. Hasil perhitungan untuk uji normalitas dapat dilihat pada Tabel 1 berikut:

Tabel 1. Hasil Uji Normalitas N-Gain MCS

\begin{tabular}{|c|c|c|c|c|c|}
\hline \multirow{2}{*}{ Kategori } & \multirow{2}{*}{ Kelas } & \multicolumn{3}{|c|}{ Shapiro-Wilk } & \multirow{2}{*}{ Keterangan } \\
\hline & & Stat. & $D f$ & Sig. & \\
\hline \multirow{2}{*}{ Laki-laki } & SR & 0.921 & 11 & 0.323 & $\mathrm{H}_{0}$ diterima \\
\hline & $\mathrm{PE}$ & 0.920 & 13 & 0.254 & $\mathrm{H}_{0}$ diterima \\
\hline \multirow{2}{*}{ Perempuan } & SR & 0.934 & 15 & 0.316 & $\mathrm{H}_{0}$ diterima \\
\hline & PE & 0.892 & 13 & 0.103 & $\mathrm{H}_{0}$ diterima \\
\hline \multirow{2}{*}{ Keseluruhan } & SR & 0.933 & 26 & 0.089 & $\mathrm{H}_{0}$ diterima \\
\hline & PE & 0.959 & 26 & 0.377 & $\mathrm{H}_{0}$ diterima \\
\hline
\end{tabular}

Berdasarkan kriteria pengambilan keputusan, maka $\mathrm{H}_{0}$ diterima. $\mathrm{Hal}$ ini berarti data n-gain MCS yang ditinjau secara keseluruhan siswa pada kelas SR dan PE berdistribusi normal. Begitupun data n-gain MCS berdasarkan gender, baik siswa laki-laki maupun siswa perempuan pada kelas SR dan PE berdistribusi normal dan data $n$-gain MCS siswa perempuan pada kedua kelas juga berdistribusi normal.

Karena data n-gain kemampuan komunikasi matematis (MCS) berdistribusi normal maka dilanjutkan dengan uji homogenitas. Hasil perhitungan uji homogenitas dapat dilihat pada Tabel 2 berikut:

Tabel 2. Hasil Uji Homogenitas N-Gain MCS

\begin{tabular}{cccc}
\hline \multirow{2}{*}{ Data } & $\begin{array}{c}\text { Levene's Test for Equality of Variances } \\
\text { Sig }\end{array}$ & \multirow{2}{*}{ Keputusan } \\
\hline$N$-Gain & 1.325 & 0.277 & $\mathrm{H}_{0}$ diterima \\
\hline
\end{tabular}

Berdasarkan kriteria pengambilan keputusan, maka $\mathrm{H}_{0}$ diterima. Hal ini menunjukkan bahwa data $n$-gain MCS bervariansi homogen.

Karena data n-gain MCS siswa berdistribusi normal dan homogen maka untuk melakukan pengujian hipotesis yang menyatakan perbedaan rata-rata antara kelompokkelompok dalam penelitian menggunakan Analisis Varians-2 Jalan (Two Way Analysis of Variance) atau disingkat dengan ANOVA 2 Jalan (Kadir, 2015). Hasil perhitungan rerata n-gain MCS menggunakan ANOVA 2 Jalan dengan dapat dilihat pada Tabel 3. 
Tabel 3. Hasil Perhitungan ANOVA Rerata $N$-Gain Kemampuan Komunikasi Matematis

\begin{tabular}{cccccc}
\hline Sumber Varians & JK & $\mathbf{d b}$ & $\mathbf{R J K}$ & $\mathbf{F}_{\mathbf{o}}$ & $\mathbf{F}_{\text {tabel }}(\boldsymbol{\alpha}=\mathbf{0 . 0 5})$ \\
\hline Antar kelas (A) & 0.386 & 1 & 0.386 & 39.342 & 4.043 \\
Antar gender (B) & 0.011 & 1 & 0.011 & 1.156 & 4.043 \\
Interaksi kelas*gender (AB) & 0.475 & 1 & 0.475 & 4.788 & 4.043 \\
Dalam & 0.475 & 48 & 0.010 & & \\
Total & 0.952 & 51 & & & \\
\hline
\end{tabular}

Sedangkan hasil uji lanjut dengan uji t-Dunnet dapat dilihat pada Tabel 4 berikut:

Tabel 4. Hasil Uji Lanjut Kemampuan Komunikasi Matematis

\begin{tabular}{ccccc}
\hline Kategori Gender & Nilai Kontras & $(\mathbf{S e})$ & $\mathbf{t}_{\mathbf{o}}$ & $\mathbf{t}_{\text {tabel }}$ \\
\hline Laki-laki & $\left|\bar{Y}_{L S R}-\bar{Y}_{L P E}\right|=0.111$ & 0.041 & 2.72 & 1.68 \\
Perempuan & $\left|\bar{Y}_{P S R}-\bar{Y}_{P P E}\right|=0.233$ & 0.038 & 6.19 & 1.68 \\
\hline
\end{tabular}

Sebelum melakukan analisis perbedaan peningkatan kemampuan komunikasi matematis antara kelas SR dan PE, terlebih dahulu diperiksa apakah terdapat perbedaan peningkatan MCS siswa kelas SR dan PE. Dari Tabel 3 diperoleh bahwa $F_{\text {hitung(A) }}=39.342$ lebih dari $\mathrm{F}_{\mathrm{tab}}=4.043$, berdasarkan kriteria pengujian maka $\mathrm{H}_{0}$ ditolak, sehingga terdapat perbedaan peningkatan kemampuan komunikasi matematis siswa antara siswa kelas SR dan PE. Dari Tabel 3 diperoleh bahwa $F_{\text {hitung }}=39.342$. Uji satu pihak, dihitung dengan rumus $t_{\text {hitung }}=\sqrt{F_{\text {hitung }}}=\sqrt{39.342}=6.272$. Ini ternyata lebih dari $\mathrm{t}_{\mathrm{tab}}=1.68$, berarti $\mathrm{H}_{0}$ ditolak. Hal ini berarti bahwa peningkatan kemampuan komunikasi matematis siswa yang memperoleh pembelajaran melalui strategi REACT lebih tinggi daripada siswa yang memperoleh pembelajaran ekspositori ditinjau dari keseluruhan siswa.

Dari Tabel 4 diperoleh bahwa thitung pada siswa laki-laki dan perempuan yaitu berturut-turut 2.72 dan 6.19. Karena $\mathrm{t}_{\mathrm{tab}}=1.68$, maka $\mathrm{t}_{\text {hitung }}$ lebih dari $\mathrm{t}_{\mathrm{tab}}$, berarti $\mathrm{H}_{0}$ ditolak. Ini berarti bahwa peningkatan MCS siswa laki-laki kelas SR lebih tinggi daripada siswa laki-laki kelas PE dan peningkatan MCS siswa perempuan kelas SR juga lebih tinggi daripada siswa perempuan kelas PV. Dengan demikian peningkatan kemampuan komunikasi matematis siswa yang memperoleh pembelajaran melalui strategi REACT lebih tinggi daripada siswa yang memperoleh pembelajaran ekspositori ditinjau berdasarkan gender. Selanjutnya dari Tabel 3 diperoleh bahwa $F_{\text {hitung }(B)}=1.156$ kurang dari $\mathrm{F}_{\mathrm{tab}}=4.043$, berdasarkan kriteria pengujian maka $\mathrm{H}_{0}$ diterima, sehingga tidak terdapat perbedaan peningkatan kemampuan komunikasi matematis antara siswa laki-laki dan siswa perempuan yang memperoleh pembelajaran melalui strategi REACT.

Hasil penelitian yang diperoleh menggambarkan bahwa pembelajaran melalui 
strategi REACT memberikan kontribusi yang baik dalam upaya meningkatkan kemampuan komunikasi matematis siswa. Hal ini dimungkinkan karena pembelajaran telah berubah dari paradigma pembelajaran yang berpusat pada guru kepada pembelajaran yang menekankan pada keaktifan siswa yang mengkonstruksi pengetahuannnya sendiri. Crawford (2001) menyatakan bahwa strategi REACT memiliki kelebihan diantaranya dapat memperdalam pemahaman siswa serta membuat belajar menyeluruh dan menyenangkan.

Peningkatan kemampuan komunikasi matematis siswa yang memperoleh pembelajaran melalui strategi REACT lebih tinggi daripada siswa yang memperoleh pembelajaran ekspositori ditinjau dari keseluruhan siswa. Hal ini dikarenakan siswa yang memperoleh pembelajaran melalui strategi REACT lebih terbiasa menyajikan suatu masalah kehidupan sehari-hari (bukan abstrak) sehingga siswa dapat menggambarkan suatu situasi dengan persepsi yang dapat dijangkaunya.

Peningkatan kemampuan komunikasi matematis siswa laki-laki yang memperoleh pembelajaran melalui strategi REACT lebih tinggi daripada siswa laki-laki yang memperoleh pembelajaran ekspositori. Hal ini disebabkan karena siswa laki-laki yang memperoleh pembelajaran melalui strategi REACT melakukan kegiatan percobaan praktek dalam pembelajarannya yang mendorong siswa untuk meningkatkan kemampuan komunikasi matematis. Sedangkan peningkatan kemampuan komunikasi matematis siswa perempuan yang memperoleh pembelajaran melalui strategi REACT lebih tinggi daripada siswa perempuan yang memperoleh pembelajaran ekspositori. Hal ini disebabkan karena siswa perempuan yang memperoleh pembelajaran melalui strategi REACT menyelesaikan masalah yang diberikan selalu dengan bekerjasama dan berdiskusi pada kelompokkelompok kecil sehingga dapat meningkatkan kemampuan komunikasi matematisnya.

Namun tidak terdapat perbedaan peningkatan kemampuan komunikasi matematis antara siswa perempuan dan siswa laki-laki yang memperoleh pembelajaran melalui strategi REACT. Hal ini disebabkan karena peningkatan kemampuan komunikasi matematis siswa laki-laki dan siswa perempuan sama-sama berkembang dengan baik sehingga menyebabkan kemampuan mereka tidak berbeda secara signifikan.

\section{KESIMPULAN}

Berdasarkan hasil pembahasan di atas dapat disimpulkan bahwa: 1) peningkatan kemampuan komunikasi matematis siswa yang memperoleh pembelajaran melalui strategi REACT lebih tinggi daripada siswa yang memperoleh pembelajaran ekspositori ditinjau 
dari keseluruhan siswa, 2) peningkatan kemampuan komunikasi matematis siswa laki-laki yang memperoleh pembelajaran melalui strategi REACT lebih tinggi daripada siswa lakilaki yang memperoleh pembelajaran ekspositori 3) peningkatan kemampuan komunikasi matematis siswa perempuan yang memperoleh pembelajaran melalui strategi REACT lebih tinggi daripada siswa perempuan yang memperoleh pembelajaran ekspositori, 4) tidak terdapat perbedaan peningkatan kemampuan komunikasi matematis antara siswa perempuan dan siswa laki-laki yang memperoleh pembelajaran melalui strategi REACT.

\section{REFERENSI}

Amin, M. S. (2018). Perbedaan Struktur Otak dan Perilaku Belajar Antara Pria dan Wanita; Eksplanasi dalam Sudut Pandang Neuro Sains dan Filsafat. Jurnal Filsafat Indonesia, 1(1), 38-43.

Ansari, B. . (2012). Komunikasi Matematik dan Politik. Banda Aceh: Yayasan Pena.

Bell, F. H. (1978). Teaching and Learning Mathematics (In Secondary School). Amerika: Wm. C. Brown Company Publisher.

Crawford, M. L. (2001). Teaching Contextually. Research, Rationale, and Technique for Improving Student Motivation and Achievement in Mathematics Science. Texas: CCT Publishing, Ins.

Husna, F. El, Dewi, F., \& Murni, D. (2014). Kemampuan Pemahaman Konsep Matematika Siswa Kelas X SMAN 1 Batang Anai. Jurnal Pendidikan Matematika, 3(1), 26-30.

Kadir. (2015). Statistika Terapan: Konsep, Contoh dan Analisis Data dengan Program SPSS/Lisrel dalam Penelitian. Jakarta: Raja Grafindo Persada.

Kaselin, Sukestiyarno, \& Waluta, B. (2013). Kemampuan komunikasi matematis pada pembelajaran matematika dengan strategi REACT berbasis etnomatematika. Unnes Journal of Mathematics Education Research, 2(2), 122-127. Retrieved from http://journal.unnes.ac.id/sju/index.php/ujmer

Keitel, C. (1998). Social Justice and Mathematics EducationGender, Class,Ethnicity and the Politics of Schooling. Berlin: Freie Universität Berlin.

Lindberg, S. M., Hyde, J. S., Petersen, J. L., \& Linn, M. C. (2010). New Trends in Gender and Mathematics Performance: A Meta-Analysis. Psychological Bulletin, 136(6), 1123-1135. https://doi.org/10.1037/a0021276

NCTM. (2000). Principles and Standards for School Mathematics. Virginia.

Nugraha, T. H., \& Pujiastuti, H. (2019). Analisis Kemampuan Komunikasi Matematis Siswa Berdasarkan Perbedaan Gender. Edumatica Unja.

OECD. (2016). Programme for International Student Assesment (PISA) Result from PISA 2015, 1-8.

Prayitno, S., Suwarsono, \& Siswono, T. Y. (2013). Identifikasi Indikator Kemampuan Komunikasi Matematis Siswa dalam Menyelesaikan Soal Matematika Berjenjang pada Tiap-Tiap Jenjangnya. In Konferensi Nasional Pendidikan Matematika V. Malang: Universitas Negeri Malang.

Sugiyono. (2013). Metode Penelitian Pendidikan (Pendekatan Kuantitatif, Kualitatif, dan $R \& D)$. Bandung: Alfabeta.

Suhena, E. (2009). Pengaruh Strategi REACT dalam Pembelajaran Matematika Terhadap Kemampuan Pemahaman, Penalaran, dan Komunikasi Matematis Siswa SMP. Jurdikmat FPMIPA UPI Bandung. 
Sumarmo, U. (2003). Pembelajaran Keterampilan Membaca Matematika. Bandung: FPMIPA UPI.

Tapilouw, M. (2010). Pembelajaran melalui Pendekatan REACT Meningkatkan Kemampuan Matematis Siswa SMP. Jurnal Penelitian Pendidikan, 11(2), 129-141.

Wardhani, S., \& Rumiati. (2011). Instrumen Penilaian Hasil Belajar Matematika SMP: Belajar dari PISA dan TIMSS. Yogyakarta. 